PIOTR DUCHLIŃSKI

\title{
(rec.) Dominika Dzwonkowska, Etyka cnót środowiskowych, Wydawnictwo Naukowe UKSW w Warszawie, Warszawa 2019, ss. 367.
}

Czasy współczesne - jak podkreślają znawcy tematu - naznaczone są wielowymiarowym kryzysem ekologicznym, który spowodowany jest nieodpowiedzialną i nieracjonalną działalnością człowieka wobec środowiska naturalnego. Aby zaradzić nasilającemu się w różnych obszarach globu ziemskiego kryzysowi, podejmowane są kompleksowe działania, angażujące prominentnych polityków, prawników, ekonomistów i biznesmenów. Wszystkim przyświeca szczytny (jak się wydaje) cel - zabezpieczenie przed degradacją różnych dóbr naturalnego środowiska, bez którego człowiek nie może przetrwać. Również i filozofowie mają w tych działaniach swój ważny udział, wyrażający się chociażby w formułowaniu różnych diagnoz, w których ukazywane są przyczyny pogłębiającego się kryzysu. W ostatnich latach możemy obserwować stale wzrastającą ilość prac naukowych i popularnonaukowych, dotyczących problematyki ekologicznej. Ilość prowadzonych badań naukowych, realizowanych grantów i projektów badawczych, wspieranych przez administracje rządową, jest wręcz imponująca i pokazuje, że jednak w ostatnich latach coś drgnęło w ludzkiej świadomości, jeśli chodzi o ochronę naturalnych ekosystemów. Również w Polsce od ponad trzydziestu lat intensywnie rozwija się etyka ekologiczna, filozofia ekologii, a także różne nurty naturalistycznej i chrześcijańskiej ekofilozofii. Polska filozofia i etyka środowiskowa jest mocno spluralizowana; występujące w niej nurty są mniej lub bardziej oryginalne, proponowane przez ich zwolenników recepty na zahamowanie degradacji środowiska naturalnego wzbudzają mniejsze lub większe kontrowersje. W ostatnich latach ukazało się również sporo diagnoz, które miały na celu obudzenie 
świadomości ekologicznej polskiego społeczeństwa; uwrażliwienie konsumpcyjnego społeczeństwa na zagrożenia, związane z nieodpowiedzialną eksploatacją dóbr środowiska naturalnego, które w niedalekiej przyszłości mogą doprowadzić nawet do wyginięcia gatunku homo sapiens. Przybierający na sile kryzys ekologiczny motywuje filozofów, pracujących w różnych tradycjach badawczych, do opracowywania nowych projektów etycznych i strategii ekologicznych, które miałyby nie tylko teoretyczny, ale przede wszystkim praktyczny wymiar: dostarczałyby operatywnych narzędzi do podejmowania racjonalnych działań, zmierzających do niwelowania przynajmniej jakiejś części skutków degradacji naturalnego środowiska. Ostatnio z takim właśnie poważnym projektem etyki ekologicznej wystąpiła Dominika Dzwonkowska z Uniwersytetu Kardynała Stefana Wyszyńskiego w Warszawie w monografii pt.: Etyka cnót środowiskowych. Autorka przedstawiła w niej interesujący poznawczo projekt (prototeorię) etyki cnót środowiskowych, który w moim przekonaniu, bezwzględnie zasługuje na pozytywną uwagę i krytyczną dyskusję.

Recenzowana monografia strukturalnie została podzielona na: wstęp, trzy części, zakończenie, bibliografię przedmiotową, indeks osobowy $\mathrm{i}$ indeks rzeczowy oraz streszczenie $\mathrm{w}$ języku angielskim. We wstępie Dzwonkowska uzasadnia wybór podjętego tematu oraz formułuje cele badawcze, jakie zamierza osiągnąć. „Pisaniu tej książki towarzyszyła chęć ukazania, że kwestia sprawności moralnych podmiotu moralnego ma kluczowe znaczenie dla etycznego postępowania" (s. 8). Autorce chodzi zwłaszcza o ,aplikację etyki cnót środowiskowych do debaty nad stanem środowiska naturalnego, poszukując odpowiedzi na wybrane pytania szczegółowe i problemy, jakie rodzą się w tej dyskusji” (s. 8). Autorka broni dwóch zasadniczych tez: (1) Etyka cnót środowiskowych powinna uwzględniać uniwersalistyczną, pozytywną i praktyczną naturę cnót, oraz (2) praktyczny wymiar cnót wymaga dostosowania pojęć filozoficznych do praktycznego charakteru cnoty. W związku z tym konieczne jest poszerzenie języka etyki cnót o pojęcia filozoficzne uwzględniające sferę praxis. Autorka 
zmierza do odpowiedzi na następujące pytania: Czym jest cnota i wada środowiskowa? Jaki wpływ na podmiot moralny ma realizacja cnót środowiskowych w kontekście kształtowania doskonałości moralnej? Czym cnoty i wady środowiskowe różnią się od innych cnót i wad? Czy najbardziej antropocentryczna teoria etyczna może być panaceum na bolączki antropocenu? Czy etyka cnót środowiskowych może w jakiś sposób przyczynić się do rozwiązania problemu degradacji środowiska naturalnego, w którym żyje człowiek? Czy wada i cnota powinny być określane jako ekologiczne, czy też raczej jako środowiskowe? Stwierdza, że „celem niniejszej monografii jest przedstawienie zarysu koncepcji uniwersalistycznej, pozytywnej i praktycznej etyki cnót środowiskowych" (s. 9). Autorka zmierza do wypracowania nowatorskiej koncepcji cnót środowiskowych, która przezwyciężałaby ograniczenia różnych koncepcji etyki cnót środowiskowych, jakie w XX wieku pojawiły się na areopagu myśli ogólnoświatowej.

Część pierwsza monografii zawiera ogólne wprowadzenie w problematykę etyki cnót, w którym Autorka zapoznaje czytelnika z podstawowymi pojęciami i problemami dyskutowanymi w ramach różnych koncepcji etyki cnót. W części drugiej przeprowadza rekonstrukcję trzech głównych koncepcji etyki cnót środowiskowych, które ukształtowały współczesny dyskurs etyki środowiskowej. W trzeciej części Autorka krytycznie dyskutuje walory i wady zrekonstruowanych koncepcji cnót środowiskowych i na tej podstawie formułuje własną autorską propozycję etyki cnót środowiskowych, która ma na celu przezwyciężenie ograniczeń omówionych koncepcji. Monografię zamyka syntetyczne zakończenie, w którym Autorka dokonuje rekapitulacji przeprowadzonych badań oraz wskazuje na problemy, które powinny być przebadane $\mathrm{w}$ przyszłości.

Zaprezentowane $\mathrm{w}$ książce analizy zostały sformułowane w języku przedmiotowym i metajęzyku. Choć sama Autorka wprost o tym nie pisze, przedmiotem stosowanej przez nią analizy hermeneutyczno-analitycznej są zasadniczo książki i artykuły różnych 
anglojęzycznych autorów, zajmujących się etyką cnót środowiskowych oraz ich uczniów, pochodzące $\mathrm{z}$ różnych okresów ich twórczości, a także poglądy filozoficzne, do których autorzy ci nawiązywali (aprobująco lub też krytycznie); opracowania ich dorobku oraz prace filozoficzne, ważne dla względnie całościowej oceny ich dorobku oraz przydatne dla wypracowania własnej nowatorskiej koncepcji etyki cnót środowiskowych. W rezultacie otrzymujemy klarowną parafrazę oraz interesującą poznawczo reinterpretację różnych poglądów, dotyczących etyki cnót środowiskowych. Autorka posługuje się także metodą komparatystyczną (ale tylko kontekstowo), aby uwyraźnić czytelnikowi zajmowane przez nią stanowisko w sporze o etykę cnót środowiskowych.

W swojej recenzji w pierwszej kolejności chciałbym skupić się na walorach rozprawy. Walory te pokazują, w moim przekonaniu, że warto sięgnąć po pracę Etyka cnót środowiskowych, aby nie tylko zdobyć dosyć gruntowaną wiedzę o etyce cnót środowiskowych, ale też aby dostrzec pewne ważkie dla naszej biologicznej egzystencji praktyczne problemy, związane $\mathrm{z}$ ochroną środowiska naturalnego. Choć prac (monografii i artykułów) na temat etyki ekologicznej w Polsce powstało w ostatnim trzydziestoleciu co najmniej kilkanaście, to jednak monografia Dominiki Dzwonkowskiej jest pierwszą pracą w polskiej literaturze przedmiotu, która zawiera całościowe i kompleksowe opracowanie etyki cnót środowiskowych w odniesieniu do problematyki ochrony środowiska naturalnego, biorąc pod uwagę dotychczasowy stan badań w tej dziedzinie wiedzy, opracowany zwłaszcza przez autorów zagranicznych, w przeważającej większości nie znanych jeszcze polskiemu czytelnikowi. Uważam bowiem, że już samo podjęcie tak trudnego problemu w kontekście obecnych wyzwań, związanych z ochroną środowiska, i kontrowersji ideologicznych, które stale im towarzyszą, zasługuje na pokreślenie i uznanie. Niniejsza monografia zachęca czytelnika do refleksji, prowokuje do formułowania pytań, skłania do krytycznego myślenia, ale przede wszystkim, apelując do naszej świadomości, pragnie 
uwrażliwić nas na znaczenie zagrożeń, które dotykają środowisko naturalne. Wykorzystanie etyki cnót do opisu i wyjaśnienia współczesnych dylematów, związanych z ochroną środowiska naturalnego, uważam za heurystycznie interesujące.

Dużym walorem recenzowanej monografii jest krytyczny sposób badania problematyki współczesnej etyki cnót środowiskowych. $\mathrm{Na}$ podkreślenie zasługuje umiejętność dyskusji i krytycznej oceny różnych koncepcji etyki środowiskowej. Dzwonkowska ujawnia się jako wytrawny i krytyczny polemista, który ze spokojem krok po kroku wydobywa walory omawianych koncepcji, jak również punktuje $\mathrm{z}$ właściwym sobie wyczuciem ich słabe strony. Zaleta pracy jest odpowiedzialny, wyważony krytycyzm pełen szacunku tych myślicieli, którzy poruszają się w odmiennych tradycjach badawczych niż Autorka. Krytycyzm ten świadczy o samodzielności, rzetelności i odwadze Autorki, która nie boi się formułować trudne pytania i udzielać na nie mniej lub bardziej przekonujących odpowiedzi. Wszak Autorkę nie interesuje tylko biernie referowanie poglądów różnych prominentnych etyków cnót środowiskowych, ale także krytyczne do nich ustosunkowanie się. Dokonując krytyki formułuje ona szereg trafnych zastrzeżeń, w niektórych miejscach podejmuje zasadną polemikę, słusznie wskazując na metodologiczne i merytoryczne ograniczenia referowanych poglądów, które wymagają uzupełnienia. Niewątpliwym walorem pracy jest wypracowana przez Autorkę nowatorska koncepcja etyki cnót środowiskowych. Inspiracji poszukuje Autorka u myślicieli zagranicznych, którzy, jak zaznaczyłem, są mało znani polskiemu czytelnikowi. Uważam, że uwzględnienie tych właśnie jeszcze mało znanych autorów sprawia, że monografia Dzwonkowskiej spełnia też funkcję popularyzująca stan badań w świecie anglosaskim. Jej propozycja krystalizuje się $\mathrm{w}$ trakcie dyskusji z trzema koncepcjami etyki środowiskowej: koncepcją autorstwa znanego amerykańskiego autora Henry'ego Thoreau; tzw. naturalistyczną koncepcją etyki cnót środowiskowych wypracowaną przez Rolanda Sandlera; oraz narracyjną koncepcją cnót, której 
autorem jest Brian Treanor. Na bazie dyskusji z tymi koncepcjami Dzwonkowska proponuje uniwersalistyczną, pozytywną i praktyczną koncepcję cnót środowiskowych, w której centralną rolę odgrywa podmiot moralny wyposażony w określone cnoty, usprawniające go do działań, mających na celu ochronę dóbr środowiska naturalnego.

Autorka słusznie zwraca uwagę na potrzebę wypracowania holistycznie pojętej koncepcji natury ludzkiej jako bazy antropologicznej dla etyki środowiskowej. W sposób wyważony podchodzi do krytyki antropocentrycznego modelu etyki, który przez zdecydowaną większość współczesnych etyków cnót środowiskowych jest kwestionowany i obwiniany za destrukcję środowiska naturalnego. Autorka opowiada się za umiarkowanym antropocentryzmem w etyce, który (w jej przekonaniu), wsparty etyką cnót, może być zasadną propozycją, diagnozującą i pokazującą sposoby wyjścia ze współczesnego kryzysu środowiskowego. Na szczególną uwagę zasługuje podkreślenie przez Dzwonkowską aspektu edukacyjnego etyki cnót środowiskowych. W pełni zgadzam się z Autorką, że współczesna edukacja ekologiczna, dotycząca różnych wymiarów ochrony środowiska naturalnego, powinna być opracowywana w perspektywie założeń etyki cnót. Programy edukacji ekologicznej - na co słusznie zwraca uwagę Autorka - powinny koncentrować się na kształtowaniu podmiotowych kompetencji, uwrażliwiających na problematykę naturalnych ekosystemów. Etyka cnót dostarcza bowiem bazy przedmiotowej dla konstrukcji szkoleń edukacyjnych, które (połączone $\mathrm{z}$ obszerną analizą studium przypadków i dylematów ekologicznych) mogą realnie przyczynić się do wzrostu świadomości ekologicznej społeczeństwa, zwłaszcza wśród ludzi młodych, których coraz mocniej pochłania konsumpcyjny styl życia. Ten praktyczny wymiar etyki cnót środowiskowych jest bardzo ważny i dobrze, że Dominika Dzwonkowska zwraca na niego uwagę, pokazując, że nie jest to jakiś abstrakcyjny problem, którym przy biurku zajmują się zawodowi filozofowie. Słusznie też podkreśla, że rozstrzygnięcia filozoficzne powinny mieć przełożenie na edukację i decyzje 
polityczne, od których w dużym stopniu zależy prawna ochrona środowiska naturalnego. Jednakże samymi regulacjami prawnymi nie da się rozstrzygnąć wszystkich problemów ochrony zagrożonego środowiska naturalnego. Pomimo że język pracy jest teoretycznie zaawansowany, Autorka unika popadania w niezrozumiały i przesadny żargon, który bardzo często odstrasza czytelników od prac filozoficznych. Zadbała też - co jest sporym atutem pracy - o walory perswazyjne pracy, które maja pozytywnie wpływać na zmianę motywacji czytelnika. Autorka dobrze kontroluje logikę wywodu, co ułatwia czytelnikowi śledzenie narracji. Zaletą pracy jest także to, że jej Autorka starała się w miarę możliwości precyzyjnie definiować omawiane kategorie pojęciowe. Czasem niepotrzebnie (w moim przekonaniu) sporo miejsca poświęca kwestiom semantycznym, ale oczywiście świadczy to o jej dobrze ukształtowanych kompetencjach metodologicznych, dużej kulturze logicznej i trosce o czytelnika, aby nie musiał zastanawiać się, co Autorka miała na myśli. Chciałbym zwrócić uwagę, że prowadzona przez Autorkę narracja - co jest szczególnym jej walorem - nie jest przeciążona cytatami. Dominka Dzwonkowska formułując swoje własne stanowisko nie zasłania się cytatami i komentarzami innych autorów, nie chowa za plecami tzw. autorytetów, co nierzadko ma miejsce w pracach z zakresu humanistyki. Umiejętnie i odważnie spożytkowuje różne koncepcje teoretyczne tak, aby wyinterpretować $\mathrm{z}$ nich swoją własną prototeorię cnót środowiskowych. Kompetentnie łączy zdolność analizy różnych partykularnych aspektów z syntezą, za pomocą której zmierza do przedstawienia własnej propozycji teoretycznej. Monografia Dominiki Dzwonkowskiej - w moje ocenie - ma charakter analityczny i erudycyjny. Czytając ją nabieramy stopniowego przekonania, że jej Autorka jest wszechstronną badaczką, która swobodnie porusza się po bardzo szerokim obszarze zagadnień problemowych, należących do dziedziny etyki środowiskowej. Na każdej stronie rozprawy widać pełne zaangażowania zmaganie Autorki z trudną „materią” problemów etycznych i ekologicznych. Dzwonkowska zaproponowała 
interesującą poznawczo prototeorię cnót środowiskowych, która, jak podejrzewam, pełniejszy kształt znajdzie w innych publikacjach. Bez wątpienia swoją rozprawą Autorka wpisuje się we współczesne debaty, dotyczące etycznych aspektów ochrony środowiska naturalnego.

Podczas lektury monografii dostrzegłem różne wady, które odnoszą się do kwestii formalno-strukturalnych oraz merytorycznych. Pierwsza dostrzeżona wada odnosi się do konstrukcji książki i uporządkowania prezentowanych zagadnień. Dotyczy zwłaszcza pierwszej części, w której Dzwonkowska przedstawia szereg ogólnych, a czasem wręcz ogólnikowych informacji na temat historii etyki cnót i problemów badawczych, podejmowanych przez jej prominentnych zwolenników. Generalnie przedstawia sprawy czytelnikowi dobrze znane, które w polskiej literaturze przedmiotu były już wielokrotnie omawiane przez różnych autorów, których zresztą Autorka skrupulatnie wylicza. Uważam, że szereg kwestii, dotyczących stanu badań nad etyką cnót powinno być przedstawionych już we wstępie książki. Natomiast w pierwszym rozdziale Autorka mogła więcej uwagi poświęcić historii kształtowania się etyki cnót środowiskowych. Również szereg analiz językowych, przedstawionych przez Autorkę w części pierwszej, jest dobrze znanych. Moim zdaniem precyzowanie znaczenia pojęć: „cnota” czy „wada” nie było aż tak bardzo potrzebne, albowiem na ten temat wylano już tony atramentu w polskiej filozofii. Wszelkie ustalenia znaczeniowe miałyby jakiś walor poznawczy tylko wtedy, gdyby w rodzimej literaturze przedmiotu brakowało na ten temat stosownych opracowań. Wadą pracy jest także, w moim przekonaniu, niedopracowana teoretycznie koncepcja natury ludzkiej. Autorka słusznie twierdzi, że trzeba sformułować właściwą koncepcję natury ludzkiej, gdyż etyka cnót nie może się obyć bez solidnego fundamentu antropologicznego. Ten fundament nie został w recenzowanej monografii należycie dopracowany. Nie posądzam Autorki o brak wiedzy o naturze ludzkiej, dziwi mnie tylko jej oszczędność teoretyczna wobec tak istotnego zagadnienia. 
W swojej oszczędności Dzwonkowska wygłasza jednak kilka ogólnych tez na temat natury ludzkiej, które - jak uważam - można zakwalifikować do naturalizmu. Zresztą kwestia naturalizmu, za którym opowiada się Autorka, też nie jest wyraźnie sprecyzowana. Pojęcie „natury”, którym Autorka się posługuje, wymaga, w mojej ocenie, solidnego doprecyzowania znaczeniowego i przedmiotowego. Nie bardzo wiadomo, jakie elementy konstytutywne a jakie konsekutywne składają się na ludzką naturę. Autorka wyraźnie opowiada się za stałością natury ludzkiej, ale nie pisze, co o tej stałości miałoby w ostateczności decydować. W tym kontekście przydałoby się poszerzyć panel dyskutantów i uwzględnić różnej maści relatywistów kulturowych, którzy radykalnie zaprzeczają istnieniu stałej i niezmiennej natury ludzkiej. Nie bardzo też wiadomo, jak należy rozumieć normatywność natury ludzkiej, jeśli jest ona pojmowana w sposób naturalistyczny. W jaki sposób pogodzić naturalistycznie pojmowaną naturę z normatywnym charakterem cnót? Generalnie w odniesieniu do problemu natury ludzkiej Autorka wygłasza, jak wspomniałem, kilka tez, dla uzasadnienia których nie przytacza żadnego szerszego kontekstu teoretycznego.

Kolejna wątpliwość dotyczy ograniczenia praktycznego wymiaru etyki tylko do wymiaru edukacyjnego. W mojej ocenie w pracy brakuje przywołania kwestii praktycznych, dotyczących problematyki tzw. dylematów ekologicznych, które dzisiaj szeroko dyskutuje się w ramach analizy różnych case studies. Dzwonkowska przedstawiła pewną prototeorię etyki cnót środowiskowych, ale nie pokazała, jak ona „pracuje” w praktyce; jak za pomocą konceptualnych narzędzi tej etyki można by rozstrzygać konkretne dylematy moralne związane z ochroną środowiska naturalnego. W pracy zabrakło mi praktycznych studiów nad obecnymi dylematami ekologicznymi, o których sporo pisze się w literaturze naukowej i popularnonaukowej. Gdyby Autorka podała jakieś przykłady ilustrujące, jak jej koncepcja rozwiązuje te problemy, wówczas sformułowane przez Nią postulaty byłyby znacznie bardziej przekonujące, zwłaszcza dla czytelnika, który 
zainteresowany kwestiami ekologicznymi spodziewa się otrzymania do ręki praktycznych narzędzi, a nie tylko suchej teorii. W mojej ocenie proporcja między teorią a praktyka w książce Dominiki Dzwonkowskiej jest zachwiana. Jednakże odpowiedź na te kwestie wymagałaby rozbudowania warstwy teoretyczno-praktycznej, w której najpierw należałoby zdefiniować sprawozdawczo lub projektująco dylemat w odniesieniu do etyki cnót środowiska naturalnego, a następnie przeprowadzono by badania o charakterze operacjonalizujacym, które pokazałyby, w jaki sposób etyka ta w takim kształcie, jaki proponuje Dzwonkowska, pomaga nam rozstrzygać dylematy moralne, pojawiające się w relacji człowiek - środowisko naturalne.

Kontynuując uwagi krytyczne, chciałbym zwrócić uwagę na brak dopracowania kwestii normatywnych, związanych z etyką cnót środowiskowych. Problematyka normatywności cnót, jest przez Autorkę Etyki cnót środowiskowych bardzo skąpo przedstawiona. Poza kilkoma ogólnymi tezami, jakie formułuje Autorka, problem ten nie został przez nią podjęty w sposób satysfakcjonujący. Przedstawiona koncepcja etyki cnót jest, $\mathrm{w}$ moim przekonaniu, także słabo powiązana z koncepcją sprawczości. Oczywiście Autorka podkreśla, że cnoty usposabiają podmiot do określonego działania, mającego na uwadze środowisko naturalne, że wpływają na to, w jaki sposób oceniamy różne sytuacje, ale nie wykazuje, w jaki sposób to się dzieje. W moim przekonaniu w analizach Dominiki Dzwonkowskiej ginie problematyka działania i czynu, czyli tego, co podlega moralnej kwalifikacji. Przecież zgodnie z etyką klasyczną ocena moralna pod kątem dobra i zła odnosi się przede wszystkim do czynu, zakłada pewną wizję sprawczości podmiotu moralnego, który jest zdolny do działań względnie autonomicznych. Autorka, skupiając się tak mocno na tematyce cnót i kształtowaniu charakteru, traci z oczu problem sprawczości podmiotu, który był tak ważny dla etyki klasycznej, w której aretologia odgrywała istotną rolę w usprawnieniu podmiotu do działania moralnie dobrego (por. np. T. Ślipko). Tym bowiem, co podlega normatywnej ocenie w kontekście ochrony 
naturalnego środowiska, są przede wszystkim działania człowieka, które niszczą różne dobra naturalnego środowiska. Nie znalazłem jednak w recenzowanej monografii szerzej omówionego zagadnienia sprawczości oraz treściowego powiązana go z proponowaną wizją etyki cnót środowiskowych. Studiując rozprawę trudno odmówić Autorce kompetencji w sprawnym krytykowaniu poglądów tych, z którymi się nie zgadza. Inaczej sprawa wygląda z tzw. autokrytyką, której nieobecność, zwłaszcza w ostatniej części, wyraźnie rzuca się w oczy. Dominika Dzwonkowska proponuje nam bowiem pewną prototeorię cnót środowiskowych jako alternatywę dla krytykowanych przez nią koncepcji, które ujawniają określone braki, stąd też domagają się przepracowania. Sformułowaniu autorskiej propozycji - co niezaprzeczalnie jest walorem pracy - nie towarzyszy jednak krytyczna refleksja metaprzedmiotowa. W mojej ocenie w pracy zabrakło krytycznego ustosunkowania się Dzwonkowskiej do własnej koncepcji. Autorka ogranicza się raczej do pozytywnego wykładu swojej propozycji, mniej natomiast interesują ją przedmiotowe i metaprzedmiotowe trudności i ograniczenia, które koncepcja ta może generować, zwłaszcza w obszarze praktycznej operacjonalizacji. Czytając monografię nabyłem przeświadczenia - być może zresztą nieuzasadnionego - że Autorka usilnie chce przekonać czytelnika, że jej propozycja nie posiada żadnych wad teoretycznych. Czyżby zatem uważała, że Jej koncepcja jest bezdyskusyjna? Nie podejrzewam Autorki o nieumiejętność przeprowadzenia takiej autokrytyki. Jestem wręcz przekonany o tym, że jest ona świadoma różnych mankamentów sformułowanej propozycji, tylko z pewnych względów nie chciała poinformować o tym czytelnika, który o takich mankamentach, widzianych okiem samego autora, chciałby przeczytać. Być może, na co zwróciłem uwagę, chodziło jej przede wszystkim o pozytywny wykład swojej koncepcji, a nie zbytnie jej problematyzowanie. Zwłaszcza że przedstawiona przez Dominikę Dzwonkowską propozycja ma raczej postać prototeorii, a nie gotowej i wykończonej teorii. Można by zatem usprawiedliwić postepowanie 
Autorki tym, że na etapie konstrukcji prototeorii nie ma sensu przeprowadzanie zaawansowanej krytyki, która podważałaby coś, co nie zostało jeszcze opracowane. $Z$ podobną sytuacją mamy przecież do czynienia w naukach empirycznych.

Autorka chciała przedstawić określone rozwiązanie problemu badawczego, zapomniała jednak o poczynieniu pewnych zastrzeżeń, które w oczach czytelnika mogłyby, w jakimś stopniu, usprawiedliwiać teoretyczne niedociągnięcia proponowanej koncepcji. I choć Dominika Dzwonkowska nie dokonała - i chyba dobrze się stało - rewolucji w etyce cnót środowiskowych, to jednak chciałbym zaznaczyć, że nowatorstwo i oryginalność jej propozycji polega przede wszystkim na nowym sposobie połączenia i reinterpretacji określonych tez przedmiotowych, występujących w różnych koncepcjach etyki środowiskowej. Wszak kiedy zastanawiamy się, na czym polega tzw. nowatorstwo w humanistyce, to musimy sobie jasno powiedzieć, że nie polega ono na stworzeniu jakiejś oryginalnej idei niczym boskie creatio ex nibilo, ale przeważnie na dostrzeżeniu jakiegoś problemu (splotu problemów), występującego w dyskutowanych teoriach, (którego przeważnie inni badacze $\mathrm{z}$ różnych względów nie dostrzegają) i zaproponowaniu jego nowej reinterpretacji teoretyczno-praktycznej. Nawet jeśli przyjąć, oczywiście z pewnymi zastrzeżeniami, że w filozofii dokonują się jakieś rewolucje, to nie muszą one oznaczać odkrywania całkiem nowych pomysłów teoretycznych. Wszak i w nauce taka sytuacja nie zawsze ma miejsce. Generalnie rzecz ujmując, prezentowana monografia pokazuje, że jej Autorka jest zdecydowaną przeciwniczką uprawiania filozofii tylko przy biurku z dala od problemów praktycznych. Swoich poszukiwań nie traktuje w kategorii realizacji akademickiego zawodu tylko zadania, związanego z podejmowaniem określonych działań, wpływających na zmianę postrzegania przez człowieka środowiska naturalnego. Postulaty upraktycznienia filozofii, a zwłaszcza etyki cnót, uprawiania jej w ścisłej współpracy z różnymi społecznymi interesariuszami są jak najbardziej słuszne i godne instytucjonalnego wsparcia. Książka 
ma niezaprzeczalnie walor perswazyjny. Mam nadzieję, że będzie miała realny wpływ na pogłębienie świadomości ekologicznej jej czytelników. Mam także nadzieję, że recenzowana monografia zostanie zauważona w naszym środowisku i wywoła niemały ferment twórczy w świadomości polskich ekofilozofow i etyków środowiskowych.

PIOTR DUCHLIŃSKI

Akademia Ignatianum w Krakowie, Instytut Filozofii,

(Jesuit University Ignatianum in Krakow, Institute of Philosophy, Poland)

ORCID: https://orcid.org/0000-0001-9480-2730

pduchlinski@o2.pl

DOI: 10.21697/spch.2021.57.R.01

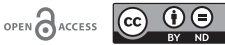

Tekst jest udostępniany na zasadach licencji Creative Commons (CC BY-ND 4.0 Międzynarodowe). Zgłoszono: 19/11/2020. Zrecenzowano: 18/12/2020. Zaakceptowano do publikacji: 09/02/2021. 